\author{
PAULA WÓJCIK ${ }^{*}$ \\ Uniwersytet Wiedeński (Austria) \\ ORCID: 0000-0003-3727-8885
}

\title{
Demony przeszłości. Więzy pamięci i tradycje powieści gotyckiej
}

\begin{abstract}
Demons of the past. Bonds of memory and traditions of the Gothic novel. The 'uncanny', according to Freud - the feeling that something familiar turns out as strange and unknown, seems to have become a leading paradigm in the memory discourse in literature. Revenants, among them zombies, golems, dybbuks, ghosts, monsters, and changelings - the whole world of the supernatural and paranormal characters brings to mind what has been forgotten within the collective memory. This paper discusses two recent manifestations of the uncanny: Szczepan Twardoch's The king of Warsaw (Król) and Jacek Dehnel's But with our dead ones (Ale z naszymi umartymi). The main objective is to examine the idea of a shadow-world as a design to analyze the multiple ways in which the past affects our present. From this perspective, the publication's title - Escape from freedom, can be understood as a poetic strategy to symbolize the determining role of the past as a 'shadow reign'.
\end{abstract}

Keywords: Gothic novel, contemporary Polish literature, the uncanny, Szczepan Twardoch, Jacek Dehnel

Od pierwszych powieści gotyckich (Gothic novel), takich jak The castle of Otranto (Zamczysko w Otranto) Horace'a Walpole'a (1764), poprzez te najbardziej znane jak Frankenstein; or, The modern Prometheus (Frankenstein, czyli wspótczesny Prometeusz) Mary Shelley (1818), The murders in the Rue Morgue (Zabójstwo przy Rue Morgue) Edgara Allana Poe (1841) i Dracula Brama Stokera (1897), do współczesnych jej odmian, określanych między innymi mianem horroru, fantasy, ghost

* Adres do korespondencji: Universität Wien, Abteilung für Vergleichende Literaturwissenschaft, Sensengasse 3a, A-1090 Wien. E-mail: paula.wojcik@univie.ac.at. 
story czy kryminału, można zaobserwować pewną tendencję. To, co anormalne, niesamowite i zdemoralizowane, nie tylko miało wywołać wśród odbiorców niepokój i dreszcz emocji, ale często służyło również krytycznej interpretacji codzienności. Ciemne strony postępu nauki, cielesność i seksualność, homoerotyzm, ksenofobicznie motywowany lęk przed zniszczeniem kultury przez „obcych”, krytyka dogmatów religijnych, kapitalizmu, rasizmu — nie ma tematu zaangażowanego społecznie, który nie zostałby opracowany w literaturze lub filmie wywodzącym się z gatunku grozy.

Od kilkunastu lat w polskiej literaturze i sztuce pojawiają się coraz częściej elementy niesamowitości i motywy dewiacji moralnych, które zdają się pełnić szczególną funkcję. Zwracają one uwagę na trudną i bolesną przeszłość lub, dokładniej, na jej zapomniane czy wyparte z pamięci zbiorowej aspekty. Innymi słowy podkreślają one to, co według Aleidy Assmann przeszło z pamięci funkcjonalnej do archiwalnej (Funktionsgedächtnis vs. Speichergedächtnis) ${ }^{1}$. Powieść Noc żywych Żydów Igora Ostachowicza (2012) czy sztuka teatralna Bożeny Keff Utwór o Matce i Ojczyźnie (2008) używają popkulturowych głosów z zaświatów, by rozliczyć się z ugładzonymi narracjami tożsamości i polskości. W obydwu przypadkach cień przeszłości materializuje się w postaciach nadnaturalnych, które zakłócają codzienność w celu ujawnienia tego, co zostało zapomniane. W obydwu przypadkach jest to „żydowska przeszłość" Polski: z jednej strony historyczna przynależność kultury żydowskiej do polskiej, z drugiej zaś antysemityzm, w świadomości społecznej nadal negowany, marginalizowany lub usprawiedliwiany, mimo licznych debat, które w sferze publicznej przybrały na sile na początku XXI wieku po publikacji Tomasza Grossa.

Ta tendencja zdaje się trwać nadal, jak ukazuje film Demon w reżyserii Marcina Wrony z roku 2015, w którym duch zamordowanej żydowskiej dziewczynki wstępuje w pana młodego w dniu ślubu. Film realizuje w formie nadprzyrodzonej abstrakcyjne wyobrażenie przeszłości, zdobywającej władzę nad teraźniejszością. Wyparta pamięć o zbrodni materializuje się w postaci dybuka, który przejmuje moc nad ciałem i rozumem mężczyzny, przypominając mu i innym o przeszłej i teraźniejszej winie: morderstwie oraz ignorancji. Film świadomie prowokuje - przeszłość żydowska zakłóca tradycjonalny rytuał wesela jako toposu kultury polskiej. To odniesienie do Wesela Stanisława Wyspiańskiego (i równocześnie do słynnej ekranizacji dramatu w reżyserii Andrzeja Wajdy) ukazuje, że połączenie tematyki niesamowitości z dyskursem pamięci zbiorowej nie jest w Polsce fenomenem nowatorskim.

Mamy więc z jednej strony tradycję anglosaskiej powieści gotyckiej (Gothic novel) i niemieckiego tak zwanego czarnego romantyzmu (schwarze Romantik), $\mathrm{z}$ drugiej zaś specyficzną tradycję polską, również wywodzącą się z literatury romantycznej, w której duchy, zjawy i upiory wchodzą w interakcję z dyskursem narodowym, co jest doskonale widoczne w Dziadach Mickiewicza czy właśnie w Weselu

1 A. Assmann, „Speichern oder Erinnern? Das kulturelle Gedächtnis zwischen Archiv und Kanon", [w:] Speicher des Gedächtnisses. Bibliotheken, Museen, Archive, wyb. M. Csásky, P. Stachel, Wien 2001, s. 15-30; eadem, Erinnerungsräume. Formen und Wandlungen des kulturellen Gedächtnisses, München 2003, s. 130-142. 
Wyspiańskiego. Literatura współczesna łączy wszystkie wymienione tradycje, odwołuje się do nich i gra nimi. Wnikliwa analiza tej tendencji może być inspirująca dla studiów zarówno nad pamięcią, jak i estetyką grozy (memory i Gothic studies) oraz wskazać na wspólne obszary badawcze między nimi.

Według Freuda to, co budzi grozę, das Unheimliche, the uncanny, to coś swojskiego, dobrze znanego, co staje się nieznane ${ }^{2}$. Niemieckie słowo wywodzi się od pojęcia „Heim”, które po polsku można przetłumaczyć jedynie częściowo adekwatnie jako 'własny dom' (w przeciwieństwie do rzeczownika „Haus”, które oznacza tylko 'dom'). Chodzi więc o własność indywidualną, o poczucie bezpieczeństwa, bycia „na swoim” i wśród swoich. Od tego pojęcia wywodzi się też trudno przetłumaczalne słowo „Heimat”, które w języku polskim oddaje zwrot 'mała ojczyzna'. Niesamowitość oznacza zatem coś znanego i swojskiego, co niespodziewanie przemienia się w coś nieznanego, wywołując i potęgując efekt grozy. Klasycznymi przypadkami są ożywające nagle przedmioty albo na odwrót - żyjący, którzy wyglądają jak martwi lub zachowują się jak automaty ${ }^{3}$.

Nietrudno zrozumieć, dlaczego powieść grozy lub jej elementy świetnie nadają się do przedstawienia historii lub raczej do rozliczenia $\mathrm{z}$ nią. Główne narracje historyczne, w których decydujące zdarzenia, role ofiar i złoczyńców są jasno określone co ma niemały wpływ na konstrukcje moralności i tożsamości społecznej - powstały w dużej mierze w XIX wieku, kiedy to w większości krajów Europy (i nie tylko) kształtowała się idea narodu, a następnie doznały częściowej transformacji po obu wojnach światowych. Ciągłość tych narracji może zostać przerwana lub przynajmniej zakłócona przez nowe, nieznane, zapominane czy przemilczane dotychczas wydarzenia albo przez zamianę ról aktorów tych wydarzeń. Przykładem jest hiszpańska wojna domowa i jej reprezentacje w czasie dyktatury generała Franco w Hiszpanii, z którymi do dziś rozliczają się literatura i film. Przemilczana lub ideologicznie przekształcona historia wychodzi z zapomnienia, odziana w kostium grozy, przyozdobiona elementami fantastycznymi, niesamowitymi i makabrycznymi, ukazując tym samym, jak pomocna może być metafora ducha lub nadprzyrodzonego stwora w przepracowywaniu przeszłości i komentowaniu wydarzeń historyczno-politycznych ${ }^{4}$.

Przydatność tej metafory można potwierdzić również w kontekście tytułu niniejszej publikacji. „Ucieczka od wolności”, którą krytycznie - aczkolwiek nie w sensie ideologicznym lub agitującym — zajmują się dwie wybrane współczesne powieści z 2016 i 2019 roku, to właśnie ucieczka do narracji historycznych, skazujących na zapomnienie wątki wstydliwe, bolesne, trudne. $W$ tych utworach wyparte pod postacią grozy wypływa z głębi zapomnienia na powierzchnię dyskursów tożsamościowych i narodowościowych. Mój wybór powieści Król Szczepana Twardocha z 2016 ro-

2 S. Freud, „Das Unheimliche”, [w:] Studienausgabe, t. 4, Psychologische Schriften, Frankfurt a. M. 2012, s. 241-274, tu s. 244.

3 Ibidem, s. 251.

${ }^{4}$ W zastępstwie licznych publikacji na ten temat zob. A. Davis, „Pleasure and historical memory in Spanish Gothic film ", Bulletin of Hispanic Studies 2019, nr 96 (4), s. 397-411. 
ku w tym zestawieniu nie jest oczywisty. Dzieło na pierwszy rzut oka nie wykazuje typowych elementów niesamowitości, takich jak duchy, wampiry czy nadnaturalne potwory. Interpretacja tekstu Twardocha w kontekście historii gatunku grozy ukazuje jednak zaskakujące powiązania, które uzasadniają przyjętą perspektywę. Drugi przykład jest pod tym względem bardziej jednoznaczny: opublikowana w 2019 roku powieść Jacka Dehnela Ale z naszymi umarłymi odnosi się do klasycznego toposu horroru: plagi zombi.

\section{Żydowski król Warszawy u Szczepana Twardocha}

Król traktuje o półświatku międzywojennej Warszawy, w którym główną rolę odgrywa były żydowski bokser Jakub Szapiro ${ }^{5}$. Tytuł i narracja powieści są przewrotne: Szapiro nie pełni funkcji głowy szajki, która z podziemia rządzi stolicą, wymuszając haracze i intrygując politycznie, a jednak mimo to jest centralną postacią utworu. Dzieje bohatera opisuje jego dawna ofiara, a późniejszy kompan, ale tylko z pozoru, gdyż jak się dowiadujemy w trakcie opowieści - to właściwie nie on, tylko sam Szapiro jako osamotniony starzec spisuje swe wspomnienia. Ich treścią są wydarzenia, które miały miejsce na krótko przed wybuchem wojny, kiedy to (antysemicka) polityka światowa mieszała się z małym światem przestępczym. W pewnym sensie Króla można byłoby zaliczyć do tradycji kryminału żydowskiego w stylu Złego Leopolda Tyrmanda, gdyż ten gatunek w ostatnich latach cieszy się nową popularnością, również poza granicami Polski ${ }^{6}$. Jeżeli cofam się dalej i wyglądam za horyzont literatury polskiej, to dlatego, że w porównaniu właśnie z pradziadkami powieści kryminalnej i klasykami tego gatunku tekst Twardocha zyskuje nowe znaczenia i potencjał krytyczny.

Figura złoczyńcy łamiącego normy moralne i krzywdzącego niewinne dziewczęta stała się znana dzięki dwóm powieściom gotyckim z przełomu XVIII i XIX wieku. Pierwsza z nich to The monk (Mnich), która w 1796 roku wyszła spod pióra młodego jeszcze Matthew Lewisa i osiągnęła ogromny sukces w całej Europie ${ }^{7}$. The monk to rozbudowana historia mnicha o imieniu Ambrosio, opowiadająca o pożądaniu seksualnym oraz perypetiach miłosnych, łącząc je z krytyką kościoła. Fabułę można streścić następująco: Ambrosio, znany i uwielbiany niemal jak celebryta za swoje wyrafinowane retorycznie kazania, zakochuje się w młodej, niewinnej Antonii. Od tej chwili jego celem jest posiąść dziewczynę, do czego dąży bezkompromisowo, umilając sobie w międzyczasie chwile miłosnymi zabawami z demoniczną Matyldą, która wkrada się w przebraniu mnicha (Rosario) do klasztoru, uwodzi Ambrosia i pomaga mu zbezcześcić biedną Antonię. Historia ukazuje okrucieństwo i hipokryzję przedstawicieli Kościoła. Druga powieść to Elixiere des Teufels (Diable elik-

5 S. Twardoch, Król, Kraków 2019 [2016].

${ }^{6}$ M. Waligórska, „The Jewish-theme whodunnit in contemporary Poland and Germany”, East European Jewish Affairs 2013, nr 43 (2), s. 143-161.

7 M.G. Lewis, The monk. A romance, London 1998 [1796]. 
siry) E.T.A. Hoffmanna ${ }^{8}$, w której powraca wiele wątków z powieści The monk. Sytuacja wyjściowa jest podobna: mnich, tym razem o imieniu Medard, zakochuje się w obrazie świętej Rozalii, który tak naprawdę ukazuje Wenus. Rozpoznaje piękną świętą w młodziutkiej Aurelii i zamierza ją posiąść. Obie powieści łączą więc z jednej strony charyzmatyczna postać utalentowanego oratorsko mnicha, z drugiej zaś jego przestępstwo: nieodpowiednie dla stanu duchownego pożądanie cielesne niewinnej dziewicy. Elixiere des Teufels różni się od The monk głównie tym, że perypetie Medarda nie są jego osobistym przewinieniem, lecz wynikiem grzechu pierworodnego — kazirodztwa jego pradziadków, powtarzającego się przez kolejne pokolenia aż do Medarda i Aurelii, która pod koniec powieści okazuję się jego przyrodnią siostrą. Cała fabuła opiera się więc na zawiłej historii rodzinnej, choć i tu dochodzi do głosu krytyka dogmatów kościelnych, wrogich życiu i cielesności. Druga różnica odnosi się do motywu sobowtóra, dodanego przez Hoffmanna. Medard pije (lub sobie to wyobraża) diabli eliksir, znajdujący się w klasztornej komnacie z relikwiami, i traci rozum. Kiedy ucieka z klasztoru, zabija przez pomyłkę swego brata przyrodniego i zajmuje jego miejsce. Brat z kolei nie umiera, lecz błąka się szalony w przebraniu Medarda, mordując i gwałcąc, co zresztą robi też sam Medard. Sobowtór symbolizuje schizofreniczne rozdwojenie jaźni lub wcielenie traumatycznych przeżyć w „inną” osobę. Zainteresowanie Hoffmanna procesami i fenomenami psychologicznymi ante litteram znane jest też z jego bodaj najpopularniejszego opowiadania Der Sandmann (Piaskun), którym między innymi inspirował się Freud, pisząc swój esej o niesamowitości.

Obie powieści wyróżniają się również obszernymi opisami zjawiska przemocy i przygód seksualnych, antycypując tym samym gatunek horroru. W The monk okrucieństwa, takie jak morderstwa i gwałty, kulminują w historii młodej zakonnicy, która zaszła w ciążę, a dziecko rodzi uwięziona w podziemiach przez brutalną przełożoną. Ponieważ jest głodzona i nie może wykarmić noworodka, ten umiera, a zakonnica jeszcze długo, tracąc rozum, opiekuje się jego martwym ciałem. Tak przesadnie okrutnego obrazu nie ma u Hoffmanna, jednak liczba morderstw i wymiar seksualnych dewiacji zasługują i tu na uwagę. Ponadto w obu przypadkach główną rolę odgrywa złoczyńca, który mimo swych niemoralnych czynów wzbudza pewną sympatię. To tyczy się zwłaszcza powieści E.T.A. Hoffmanna - przeważają w niej zwierzenia oraz długie passusy w formie listów. Głęboka introspekcja postaci wzbudza współczucie dla udręczonej duszy bohatera.

Wracając do Króla - sytuacja narracyjna u Twardocha jest podobna do tej u Hoffmanna. Narratorem jest tu pozornie Mojżesz Bernstein, spisujący swe wspomnienia. Jego ojciec został zamordowany przez Jakuba Szapirę, ponieważ jako biedny sklepikarz nie mógł opłacić haraczu, który przez zawyżone odsetki urósł do nieosiągalnej sumy. Mały Mojżesz jest świadkiem, jak ojciec jest „ciągnięty za swoją długą,

${ }^{8}$ E.T.A. Hoffmann, „Die Elixiere des Teufels”, [w:] Werke 1814-1816, red. H. Steinecke, G. Allroggen, Frankfurt a. M. 2007. 
siwą brodę" $\mathrm{z}$ mieszkania, jego bestialskiego zabójstwa jednak nie widzi. Sklepikarz zostaje potraktowany „jak bydle" ${ }^{10}$, jego zwłoki oprawiono jak mięso w rzeźni:

Najpierw oddzielili od korpusu głowę [...]. Piły nie używali. Ręce i nogi ojca oddzielili od ciała, tnąc precyzyjnie dookoła stawów biodrowych [...], następnie preparując i przecinając ścięgna i torebki stawowe. Kości, pozbawione tych więzów, z łatwością wykręcili i wyrwali ze stawów, ciało mojego ojca rozdzierając na części ${ }^{11}$.

Opis podkreśla przemoc, oscylującą pomiędzy kontrolowanym ekscesem a profesjonalną obojętnością: jeden z oprawców, czekając „aż ojciec się wykrwawi”, spożywa „przygotowaną przez żonę kanapkę" ${ }^{2}$. Ten typ złoczyńcy w wersji nowoczesnej utrwalił się w popkulturze najpóźniej od czasu, kiedy w 1991 roku Bret Easton Ellis skonstruował w ten sposób swojego American psycho - jeden z najbardziej znanych i krytycznych w stosunku do społeczeństwa horrorów. Wszakże bohaterem powieści jest tu zblazowany amerykański yuppie lat osiemdziesiątych ubiegłego wieku, który okazuje się seryjnym mordercą.

Patrick Bateman, bohater kultowej powieści Ellisa i godny postmodernistyczny dziedzic złoczyńców pierwszych powieści gotyckich, jest tuż obok postaci mafiosa w stylu Ojca chrzestnego prototypem konstrukcji Jakuba Szapiry i jego szefa, Kaplicy, dźwięcznie nazywanego Kumem, który - choć wspiera ruch socjalistyczno-robotniczy - równocześnie bez skrupułów wyciska z właścicieli sklepów, restauracji i domów publicznych ostatni grosz. Na nawiązania Twardocha do American psycho i filmów gangsterskich wskazuje też stylizacja bohaterów Króla na dandysów: w oczy rzucają się ich hedonistyczny stosunek do alkoholu, jedzenia (szczególnie niekoszernego mięsa) i seksu, zamiłowanie do eleganckich ubrań, snobizm i przechwalanie się samochodami. Szczególnie seks zajmuje dużo miejsca w powieści - sceny erotyczne rozgrywają się najczęściej w burdelu prowadzonym przez Ryfkę, byłą (i przyszłą) kochankę Szapiry. Tu członkowie szajki Kuma podobnie jak ich wrogowie spotykają się regularnie. Sposób, w jaki obchodzą się z kobietami tam pracującymi, urasta do brutalności niebywałych rozmiarów i przywodzi na myśl sławną (i nie bez powodu nieprzyjętą w ostatecznej wersji filmu) scenę z American psycho, w której Parick Bateman wpuszcza wygłodzonego szczura do pochwy swej ofiary. Młode prostytutki w Królu są bite, gwałcone i rozszarpywane przez męskie genitalia. W tym wszystkim Szapiro jest najporządniejszy, bo nigdy nie dopuszcza się (przesadnej) przemocy wobec kobiet, choć notorycznie zdradza swoją żonę między innymi z Ryfką. Tekst koncentruje się na bujnym życiu erotycznym bohatera, szczegółowo opisując jego wykroczenia w tym zakresie. Żydowski mały gangster ma nie tylko żonę z dobrego domu, ale też liczne kochanki. Szczególnie mocno angażuje się w romans z córką prokuratora, Polką Anną, na której punkcie ma nie mniejszą obsesję niż Ambrosio

\footnotetext{
9 S. Twardoch, op. cit., s. 29.

10 Ibidem, s. 56.

11 Ibidem, s. 57.

12 Ibidem.
} 
i Medard szalejący za piękną Antonią i Aurelią. Anna z kolei nie okazuje się zbezczeszczoną polską dziewicą - bynajmniej, bardzo chętnie uczestniczy w seksualnych wybrykach z żydowskim bokserem o niższej pozycji społecznej.

Hedonistyczny styl życia imponuje młodemu Mojżeszowi, którego Jakub Szapiro bierze pod osobistą opiekę w pierwszej wersji opowieści. Biedny żydowski chłopiec przemienia się w eleganckiego młodzieńca, który ma powodzenie u kobiet i zakochuje się z wzajemnością w wybrance swojego serca. Początek powieści sugeruje, że Mojżesz ze swoją dziewczyną uciekli przed zagładą do Izraela, gdzie rozwiedli się, ale ona mimo wszystko nadal zajmuje się nim na starość. W chwilach, w których tok wspomnień jest przerywany, ta interpretacja rzeczywistości poddana zostaje korekcie $-\mathrm{z}$ rozmów $\mathrm{z}$ byłą żoną powoli wyłania się inna wersja wydarzeń, według której młody Mojżesz, żądny zemsty za morderstwo ojca, organizuje nieudany napad na Szapirę i zostaje przez niego zabity. W tej wersji to sam Szapiro, były olbrzym, którego swego czasu uwielbiała i obawiała się Warszawa, siedzi jako osłabiony i osamotniony osiemdziesięcioośmioletni starzec nie w Tel Awiwie, lecz w Warszawie ${ }^{13}$.

Zaburzenie osobowości, przestępstwa, które wychodzą na jaw, konstrukcja alternatywnej biografii - to elementy, które można znaleźć także w Elixiere des Teufels. W Królu motyw sobowtóra zostaje powtórzony w formie postaci Pantaleona, szalonego sojusznika Szapiry. Tu moment fantastyczno-bajkowy jest najbardziej widoczny. Pantaleon ma długie, czarne włosy, które zakrywają skandaliczny sekret: jego syjamskiego bliźniaka, który stopił się z bratem i namawia go do najgorszych czynów, głównie w stosunku do żony. W kontekście romantycznej tradycji literackiej Twardoch oferuje nam dwie możliwe interpretacje: fantastyczną, według której brat bliźniak jako element niesamowity kieruje osobowością Pantaleona, oraz realistyczną, według której stopnienie się dwóch ciał w jedno może oznaczać wyparcie przeżyć i czynów, które nie odpowiadają autokonstrukcji wierzącego katolika.

Można by uznać, że temat pogodzenia pozytywnych i negatywnych cech i czynów w jednej osobie jest niezbyt oryginalny. Jego nietypowość w Królu polega jednak na tym, że bohaterem powieści jest Żyd, którego Twardoch konstruuje jako antystereotyp. W przeciwieństwie do stereotypu wątłego i sfeminizowanego Żyda wprowadza on wysportowanego olbrzyma-boksera. Drugim oryginalnym aspektem jest konstrukcja Szapiry przeciwko filosemickiej tradycji ‘dobrego’ Żyda jako złoczyńcy, co z kolei potwierdza antysemicki stereotyp bandziora kradnącego pieniądze i wyzyskującego uczciwych (przeważnie chrześcijan). I w końcu — Szapiro jest też antystereotypem w sensie formalnym, ponieważ w ogóle nie jest stereotypowym żydowskim bohaterem, lecz typem złoczyńcy-gentlemana. Twardoch bawi się oczekiwaniami i przyzwyczajeniami czytelników. Szapiro to bohater nieprawdopodobnie ambiwalentny; aż sam nie może uwierzyć, że jest okrutnym złoczyńcą. W tradycji literackiej postacie żydowskie to częściej ofiary niż bandyci, a jeśli już, to na pewno nie gentlemani z zaawansowaną schizofrenią. Przypisanie Żydowi roli, którą pierwotnie grali

13 Ibidem, s. 398. 
duchowni katoliccy, można odczytać jako rozliczenie się z wątkami antysemickimi w kulturze europejskiej. Czy sympatia do mnichów Ambrosia i Medarda wywodzi się ze stylu narracji, czy jest też uzasadniona tym, że są wierzącymi sługami Boga i tylko zeszli na złą drogę? Czy niewłaściwe pożądanie mnicha razi mniej niż niewłaściwe pożądanie Żyda w stosunku do chrześcijańskiej Polki ze wyższej sfery zamiast do stereotypowej Żydówki? Główna żydowska bohaterka powieści, Ryfka, również nie odpowiada obrazowi ofiary, jaki szkicuje na przykład Jean-Paul Sartre ${ }^{14}$. Jest cwaną bizneswoman, która potrafi bronić zarówno siebie, jak i swojego interesu — to dzięki niej Szapiro przeżywa zagładę i jest na nią zdany na starość.

Z czysto imagologicznego punktu widzenia Szapiro jest więc anty-, a nawet anty-antystereotypem oraz równocześnie demonem przeszłości. Niepokoi jego żądza władzy, pragnienie by zostać tytułowym królem Warszawy. Za tym niepokojem stoi lęk przed żydowską władzą, wyobrażenie, z którego siłę czerpie antysemityzm, począwszy od Protokołów mędrców z Syjonu do żydokomuny. Wcieleniem tych obaw jest Jakub Szapiro jako demoniczny złoczyńca, jednak złoczyńca nie mniej (lub bardziej) wyrafinowany niż każdy inny, którego polubiliśmy w historii popkultury: Patrick Batemen, Norman Bates, Moriarty, Joker, Magneto (ten ostatni też żydowskiego pochodzenia) - podziwiani i budzący strach wnukowie Ambrosia i Medarda.

\section{Zombi w Krakowie Jacka Dehnela}

W Królu Twardocha demonem przeszłości jest bohater żydowski jako wcielenie typowo sprzecznych uprzedzeń i stereotypów antysemickich. W Ale z naszymi umarlymi Jacek Dehnel, zamiast podszytych rasizmem lęków, inscenizuje hiperbolicznie wyniosłe fantazje mesjanistyczne, które przemieniają się w demony zombi ${ }^{15}$. Tytuł powieści odnosi się bezpośrednio do problematyki narodowej i ideologii mesjanizmu. Jacek Dehnel podąża w kierunku, który szkicuje Maria Janion już na początku swojego bodaj najbardziej znanego eseju ze zbioru Do Europy tak, ale $z$ naszymi umartymi ${ }^{16}$. Janion przedstawia tu między innymi szeroko dyskutowaną teorię trzech historycznych kulminacji romantyzmu, stara się również zdefiniować postawę Czesława Miłosza wobec romantyzmu polskiego. Przytoczoną przez nią wypowiedź: „wy macie wspaniałą architekturę, sztukę, technikę, bogactwo - tak, ale ile my mamy trupów!" 17, szydzącą z polskiej martyrologii i kultu zmarłych, Jacek Dehnel bierze dosłownie. Jego książka opowiada o niesamowitym zjawisku: nagle w różnych miejscach Polski zaczynają pojawiać się trupy — zombi. Ta informacja natychmiast zyskuje rozgłos medialny, także poza granicami Polski:

14 J.P. Sartre, Réflexions sur la question juive, Paris 1976.

15 J. Dehnel, Ale z naszymi umartymi, Kraków 2019.

16 M. Janion, „Zmierzch paradygmatu”, [w:] Do Europy tak, ale z naszymi umarlymi, Warszawa 2000.

17 Ibidem, s. 20-21. 
Uśmiechnięte prezenterki i prezenterzy deklamowali kawałki o wielkim sukcesie polskiej polityki turystycznej, a wtórował rzecznik Krajowej Izby Turystyki [...], opowiadający, że do naszych pięknych gór i jezior, niepowtarzalnych w swojej urodzie i drogich sercu każdego Polaka, dołączyła oto atrakcja, jakiej nie ma nigdzie na świecie. [...] Ze wszystkich materiałów bijała duma, duma, narodowa duma, że to fenomen wyłącznie polski, [...] że prócz Chopina, Kopernika i pierogów wreszcie jakiś nowy, rdzennie piastowski cud mamy ${ }^{18}$.

Kompensacja poczucia niższości z powodu nikłych historycznych osiągnięć na światową skalę poprzez szczycenie się trupami - to nawiązanie do tez Janion i kierunek, w którym podąża powieść Dehnela. Janion — wciąż w dialogu z Miłoszem — wspomina o jego krytyce książki Juliana Krzyżanowskiego, będącej ,,zbiorem wszystkich banałów, mających utwierdzać po wieczne czasy obraz »la Pologne martyre " 19 . Negatywną ocenę Miłosz pogłębia po przejrzeniu egzemplarza tejże książki w bibliotece w Berkley, na której marginesach uwiecznione zostały uczucia czytających, dowodząc, że treść „wzbudza w czytelnikach uczucia krwiożercze”20. Od idei i dumy narodowej do ksenofobii i agresywnych fantazji imperialistycznych — tę kulminację lub antykulminację obserwujemy też w Ale z naszymi umarłymi. Początkowo pasywne i łagodne zombi szybko zaczynają imperialistyczną krucjatę. Najpierw zaczynają napadać na zagraniczne turystki i turystów w kraju ${ }^{21}$, później wyruszają za granicę, by podbić świat ${ }^{22}$. Ich ugryzienie - znamy to dobrze $\mathrm{z}$ horrorów - infekuje i przemienia ludzi w zombi, których armia rozrasta się w zatrważającym tempie. Na pytanie, kim są zombi i skąd się wzięli, powieść nie daje ostatecznej odpowiedzi. Są oni makabrycznym wcieleniem idei narodu: tracąc ludzką indywidualność, stają się częścią masy, która porusza się kierowana niewidoczną siłą, komunikując się ze światem w bezgłośny i niewidzialny sposób. Tym samym Dehnel nawiązuje do historii zombi w popkulturze made in Hollywood. Ta tradycja wywodzi się z powieści I am legend (Jestem legenda) Richarda Mathesona $\mathrm{z}$ roku 1954, gdzie występują wampiryczne 'protozombi'. Te z kolei stały się inspiracją mistrzów gatunku, takich jak George A. Romero i jego prekursorskiego filmu Night of the living dead (Noc żywych trupów) z roku 1968, który został przyjęty do zbiorów Museum of Modern Art w Nowym Jorku. W tych wersjach monstra ukazują się bez pierwotnego kontekstu religii voodoo, widocznego na przykład $\mathrm{w}$ filmie White zombie (Białe zombie) w reżyserii Victora Halperina z roku 1932. Nie ma w nich też typowej postaci władcy-arystokraty kierującego poddanymi, jakim był na przykład Dracula. Zombi funkcjonują jako kolektyw bez hierarchii, są połączeni z sobą niewidzialną nicią.

W Ale z naszymi umarlymi legiony zombi nawiązują do tradycji hollywoodzkiej w stylu Romero, równocześnie trawestując ideę romantycznego mesjanizmu: to

\footnotetext{
18 J. Dehnel, op. cit., s. 103.

19 M. Janion, op. cit., s. 21.

20 Ibidem.

21 J. Dehnel, op. cit., s. 128.

22 Ibidem, s. 189.
} 
Polak-zombi, nie bóg i nie człowiek, stwarza ludzkość według swego wizerunku. Tej blasfemii przeciwstawia się grupka sześciu osób, z których pięcioro przypadkowo mieszka razem $\mathrm{w}$ jednym $\mathrm{z}$ krakowskich bloków. Trzy pokolenia tworzą z sobą czułą rodzinę, związaną nie krwią, lecz przyjaźnią, i nieodpowiadającą wizjom kościelnokatolickim: w jej centrum znajdują się bowiem Tomek i Kuba, wieczny doktorant i dziennikarz, żyjący razem w mniej lub bardziej otwartym związku. Najbliższą im osobą jest Elunia, buntowniczka z niebiesko ufarbowanymi włosami, zajmująca się Karoliną - piętnastolatką zaniedbywaną przez matkę-dewotkę, która usiłuje wpoić jej nauki kościelne i homofobię. Z kolei starsza pani Lola jest w nieszczęśliwym związku z mężem, którego nie kocha. Po jego przemianie w zombi własnoręcznie go zabija i zakochuje się w Panie Władku, którego wszyscy omijają szerokim łukiem, ponieważ ma reputację pijaka. $\mathrm{Z}$ tego krótkiego przedstawienia postaci wyłania się obraz ludzi ukazujących bigoterię polskiego społeczeństwa i jego norm: heteroseksualności uwieńczonej ślubem kobiety z mężczyzną, wiary i bogobojności oraz tak zwanego porządnego życia, których drugą stroną są indywidualne nieszczęścia, nienawiść, obojętność i bezduszność.

Grupa bohaterów powieści próbuje uciec od plagi zombi, wyruszając w beznadziejną podróż, gdyż zombi zaczynają atakować też Polaków. Na początku pokazują się w historycznie znaczących miejscach Polski, takich jak Wawel ${ }^{23}$, gdzie doznają wzruszenia na widok relikwii - choć nie do końca wiadomo, czy nie jest to projekcja wywołana przez media. Jednak idea, że „odwieczna siła polskości, to nasze państwo podziemne..." ${ }^{24}$, ewoluuje w trakcie powieści: grupa wykształca własne rytuały i przejmuje władzę nad światem. Ironicznym wyborem jest ostatni bastion, w którym chowają się bohaterowie - klasztor na Jasnej Górze w Częstochowie. W nadziei, że natchnione duchem polskości zombi wzruszą się na widok obrazu Matki Boskiej Częstochowskiej, grupa zabarykadowuje się w miejscu bardzo symbolicznym, które przez to traci swój sakralny charakter i staje się zwyczajne, analogicznie do bastionów znanych z amerykańskiej popkultury: centrów handlowych czy domu farmera, w których często chowają się ofiary. W końcu jednak bastion pada i nawet Czarna Madonna nie jest w stanie dodać oblężonym otuchy: „Tak się patrzy spod przymrużonych powiek, oceniająca. Żadnego uśmiechu. Ani w ustach, ani w oczach. [...] Nic dziwnego, że ludzie sobie myślą, że to Polka"25. Religijne symbole nie pomagają polskość w końcu zanika, a świat przemienia się w zombiland.

Można to oczywiście odczytać jako alegorię fundamentalizmu religijno-narodowego, w którym szlachetne, wyższe ideały szybko okazują się płonne i mgliste, a pod spodem skrywają „zgniłe” antynowoczesne oblicze. Powieść jednak nie ma moralizującego zakończenia, które wyraziłoby jednoznaczną krytykę. Raczej za pomocą groteski ilustruje, w jaki sposób idea mesjanizmu może zostać wskrzeszona i przywrócona do życia w warunkach nowoczesnego społeczeństwa pluralistycznego i zarazem medialnego, w którym przetwarzane i relacjonowane jest wszystko:

\footnotetext{
23 Ibidem, s. 101

24 Ibidem, s. 160.

${ }^{25}$ Ibidem, s. 295.
}

Miscellanea Posttotalitariana Wratislaviensia 8, 2020

(C) for this edition by CNS 
Dlaczego słowo „zombi”? To nie jest polskie słowo; to jest słowo brzydkie, pospolite, kojarzące się z tanią amerykańską rozrywką i obcym katolicyzmowi kultem. Wolę to piękne określenie „antenaci”! Brońmy tego słowa od Giewontu do Bałtyku ${ }^{26}$.

Nie chodzi więc o krytykę samej romantyczności à la Miłosz, lecz sposobu, w jaki ten ideowy zombi jest wprowadzany do świata, w którym okazuje się anachronizmem. Dehnel wyraźnie pokazuje to, gdy w społeczno-politycznym talk show uczestnicy rozwodzą się nad tym, czy osiemnastowieczne zombi będą bronić praw kobiet, czy wolności religijnych ${ }^{27}$.

\section{Koniec}

Na pierwszy rzut oka trudno znaleźć punkty wspólne między powieścią Król Szczepana Twardocha i Ale z naszymi umarlymi Jacka Dehnela. Historia międzywojennego półświatka i współczesna horror-groteska różnią się treścią, jednak w kontekście kategorii niesamowitości niniejsze zestawienie zyskuje nowe znaczenia. Ucieczka od wolności to ucieczka do demonów przeszłości: do lęków i obaw, które materializują się w stereotypach, do historycznych fantazmatów wyższości. Demony te rzucają cień na zdobytą wolność i w nim przejmują władzę nad racjonalnym myśleniem społeczeństwa. Ta sytuacja przypomina scenę ze słynnej, powstałej pod koniec XVIII wieku akwaforty Francisco de Goi El sueño de la razón produce monstruos, która zdaje się patronować obu powieściom. Na obrazie widzimy śpiącego człowieka, za nim z cienia na pierwszy plan wychodzą nocne potwory. Gdy rozum śpi, potwory przejmują władzę nad rzeczywistością. W tym sensie tradycja powieści gotyckiej znakomicie nadaje się do przedstawiania wybryków uwolnionej od rozumu wyobraźni: lubieżnego żydowskiego złoczyńcy oraz makabryczno-groteskowego, imperialistycznie zabarwionego mesjanizmu, ścielących drogę od wolności.

${ }^{26}$ Ibidem, s. 132.

27 Ibidem, s. 136.

Miscellanea Posttotalitariana Wratislaviensia 8, 2020

(C) for this edition by CNS 


\section{Bibliografia}

\section{Literatura przedmiotu}

Dehnel, Jacek. 2019. Ale z naszymi umartymi. Kraków: Wydawnictwo Literackie.

Hoffmann, Ernst T.A. 2007. Die Elixiere des Teufels. W: Werke 1814-1816, red. Hartmut Steinecke, Gerhard Allroggen. Frankfurt a. M.: Deutscher Klassiker Verlag.

Lewis, Matthew G. 1998 [1796]. The monk. A romance. London: Penguin Books.

Twardoch, Szczepan. 2019 [2016]. Król. Kraków: Wydawnictwo Literackie.

\section{Literatura podmiotu}

Assmann, Aleida. 2001. Speichern oder Erinnern? Das kulturelle Gedächtnis zwischen Archiv und Kanon. W: Speicher des Gedächtnisses. Bibliotheken, Museen, Archive. Wyb. Moritz Csásky, Peter Stachel, 15-30. Wien: Passagen Verlag.

Assmann, Aleida. 2003. Erinnerungsräume. Formen und Wandlungen des kulturellen Gedächtnisses. München: Verlag C.H. Beck.

Davis, Ann. 2019. „Pleasure and historical memory in Spanish Gothic film”, Bulletin of Hispanic Studies 96, nr 4: 397-411.

Freud, Sigmund. 2012. Das Unheimliche. W: Studienausgabe, t. 4. Psychologische Schriften, 241-274. Frankfurt a. M.: S. Fischer Verlag.

Janion, Maria. 2000. Zmierzch paradygmatu. W: Do Europy tak, ale z naszymi umarlymi. Warszawa: Wydawnictwo Sic!

Sartre, Jean-Paul. 1976. Réflexions sur la question juive. Paris: Gallimard.

Waligórska, Magdalena. 2013. „The Jewish-theme whodunnit in contemporary Poland and Germany”, East European Jewish Affairs 43, nr 2: 143-161.

Przyjęto do druku/Accepted for publication: 30.09 .2020

Miscellanea Posttotalitariana Wratislaviensia 8, 2020

(C) for this edition by CNS 